\title{
Correction to: Preconditioning of Human Decidua Basalis Mesenchymal Stem/Stromal Cells with Glucose Increased Their Engraftment and Anti-diabetic Properties
}

\author{
Yasser Basmaeil ${ }^{1}{ }_{D} \cdot$ Manar Al Rashid $^{1} \cdot$ Tanvir Khatlani $^{1} \cdot$ Manal AlShabibi $^{2}$. \\ Eman Bahattab $^{2}$ - Meshan L. Abdullah ${ }^{3}$ - Fawaz Abomaray ${ }^{4}$ Bill Kalionis ${ }^{5,6}$. \\ Safia Massoudi ${ }^{7} \cdot$ Mohamed Abumaree $^{1,8}$
}

Published online: 3 May 2020

(C) The Author(s) 2020

\section{Correction to: Tissue Eng Regen Med https://doi.org/10.1007/s13770-020- 00239-7}

The author would like to correct the names for the below co-authors in the online published article.

The correct author names are given below:

Fawaz Abomaray

Mohamed Abumaree
Open Access This article is licensed under a Creative Commons Attribution 4.0 International License, which permits use, sharing, adaptation, distribution and reproduction in any medium or format, as long as you give appropriate credit to the original author(s) and the source, provide a link to the Creative Commons licence, and indicate if changes were made. The images or other third party material in this article are included in the article's Creative Commons licence, unless indicated otherwise in a credit line to the material. If material is not included in the article's Creative Commons licence and your intended use is not permitted by statutory regulation or exceeds the permitted use, you will need to obtain permission directly from the copyright holder. To view a copy of this licence, visit http://creativecommons. org/licenses/by/4.0/.
The original article can be found online at https:// doi.org/10.1007/s13770-020-00239-7.

Yasser Basmaeil

basmaeily@NGHA.MED.SA

1 Stem Cells and Regenerative Medicine Department, King Abdullah International Medical Research Center, King Abdulaziz Medical City, Ministry of National Guard Health Affairs, Mail Code 1515, P.O. Box 22490, Riyadh 11426, Kingdom of Saudi Arabia

2 National Center for Stem Cell Technology, Life Sciences and Environment Research Institute, King Abdulaziz City for Science and Technology, P.O Box 6086, Riyadh 11442, Kingdom of Saudi Arabia

3 Experimental Medicine, King Abdullah International Medical Research Center MNG-HA, Ali Al Arini, Ar Rimayah, Riyadh 11481, Kingdom of Saudi Arabia

4 Division of Obstetrics and Gynecology, Department of Clinical Science, Intervention and Technology, Karolinska Institutet, 14186 Stockholm, Sweden
5 Department of Maternal-Fetal Medicine, Pregnancy Research Centre and University of Melbourne, Parkville, VIC 3010, Australia

6 Department of Obstetrics and Gynaecology, Royal Women's Hospital, 20 Flemington Rd, Parkville, VIC 3052, Australia

7 Department of Forensic Biology, College of Forensic Sciences, Naif Arab University for Security Sciences, Khurais Rd, Ar Rimayah, Riyadh 14812, Kingdom of Saudi Arabia

8 College of Science and Health Professions, King Saud Bin Abdulaziz University for Health Sciences, King Abdulaziz Medical City, Ministry of National Guard Health Affairs, Mail Code 3124, P.O. Box 3660, Riyadh 11481, Kingdom of Saudi Arabia 